The Doctors Blackwell, Janice Nimura, W.W. Norton, 2021, pp. 268, $\$ 27.95$ hardcover.

\section{America's First Female Doctors Changed the Practice of Medicine}

\section{Robert Carle}

Janice Nimura's The Doctors Blackwell is a dazzling portrait of two obstinate, brilliant immigrant sisters who became America's first and third female medical doctors. Elizabeth and Emily Blackwell founded the New York Infirmary for Indigent Women and Children and the Women's College of Medicine, two nineteenth-century institutions that brought medicine to women and women to medicine.

Nimura constructs her biography of the Blackwell sisters from a trove of diaries and letters between the sisters, who are vivid writers, keen observers, and profound social critics. The Blackwells' descriptions of medical practices often read like passages from a gothic novel. Elizabeth and Emily studied medicine during the apex of what we now call "heroic medicine." Medicine was a matter of purging a patient with a toxic mix of laxatives, diuretics, expectorants, emetics, leeches, lances, and blisters. Doctors equated violent reactions with effective therapies. Regardless of the ailment, doctors prescribed the same handful of drugs and procedures, trying each in succession, until the patient either recovered or died.

"Heroic medicine" was a dramatic departure from the medieval model of medicine in which healers used time and nature to correct and restore the body. As empirical science and industrialization took hold in the public consciousness, the body-as-machine began to eclipse the body-as-garden image. Humans are mechanisms that, when broken, needed to be fixed. Healers who focused on long-term care-monks, nuns, and village midwives-were replaced by doctors fixated on dramatic short-term cures for which they could charge hefty fees. As doctoring became commercialized, women were excluded from the ranks of the guild.

The Blackwell sisters were born in England to a family of Protestant dissenters. Their parents, Samuel

Robert Carle is a professor of theology at The King's College in Manhattan; bcarle@tkc.edu. Dr. Carle has contributed to the Wall Street Journal, The American Interest, Newsday, Society, Human Rights Review, The Public Discourse, Academic Questions, and Reason. He last appeared in AQ with "Remembering Columbus: Blinded by Politics" in spring, 2019. 
and Hannah, were staunch Whig reformers and anti-slavery activists, and America provided an outlet for Samuel Blackwell's idealism. America was a nation founded by dissidents, and Samuel could bring his anti-slavery energy to a nation steeped in the blood of slaves. He would produce sugar without slave labor by growing sugar beets in the free state of Ohio.

When the Blackwells arrived in Ohio in 1838, Elizabeth was seventeen. She joined the temperance movement and signed a total abstinence pledge. She also took a lifelong vow of celibacy. Elizabeth was helping to raise six younger siblings. She had no desire to have children of her own.

Anti-slavery activism was the Blackwell family's primary form of social engagement. Samuel Blackwell became friends with William Lloyd Garrison and joined the Committee of Vigilance to help protect fugitive slaves from recapture. The Blackwells sheltered runaway slaves in their home, and they became congregants at Lyman Beecher's church. The Blackwells became friends with Henry Ward Beecher, Harriet Beecher Stowe, and Catherine Beecher decades before they became national figures.

Samuel Blackwell died shortly after settling in Ohio. He left his widow and nine children with twenty dollars. The necessity of earning an income fell to Elizabeth and her older sisters. Samuel's death taught his daughters that a husband was no guarantee of security. Elizabeth and her sisters fanned out across the country to work as school teachers. None of them would ever marry. Elizabeth's little brothers were drawn to activist women. Sam Blackwell married America's first female ordained minister. Henry Blackwell married suffragist Lucy Stone, the first American woman on record to keep her maiden name.

Elizabeth crossed the border into slave territory to work as a schoolmistress. The director of Elizabeth's school in Asheville, North Carolina had previously been a doctor, and Elizabeth quickly bonded with him. Dr. Dickenson borrowed a human skeleton for Elizabeth to study and supported Elizabeth's outrageous plan to become a doctor. Dr. Dickenson's brother had received a medical degree from the University of Pennsylvania, and he gave Elizabeth access to his library, which held over a thousand medical texts.

Elizabeth sent applications to twenty-nine medical schools. All rejected her. The only way forward, she was advised, was to pose as a man, an option she couldn't countenance. Elizabeth finally received admission from an obscure medical 
college in Western New York State. The admission was partly a prank and partly a strategy for the Geneva School of Medicine to attract attention to its fledgling enterprise. Elizabeth's medical education consisted of two identical sixteen week terms of lectures that were repeated in successive years. Students learned by watching and listening. They rarely interacted with patients. They graduated with a frightening level of ignorance.

In medical school, Elizabeth's professors taught her how to bloodlet and administer castor oils, calomel (a laxative compound of mercury); lobelia ("pukeweed”); mustard plaster (which caused first-degree burns); and turpentine.

Elizabeth was never convinced of the benefits of any of these therapies. In her first book, The Laws of Life, with Special Reference to the Physical Education of Girls (1859), Elizabeth made the case that hygiene and exercise, rather than pharmacology and surgery, were the true guardians of good health.

The ordeal of Elizabeth's cousin Marie at the hands of the famous Scottish doctor James Young Simpson reinforced Elizabeth's skepticism about the pretensions of heroic medicine. Simpson was the physician to the Queen of Scotland and was famous for his discovery of chloroform-a discovery he made when he offered several guests at a dinner party a whiff of the chemical poured from a brandy decanter. The room filled with a wave of giggling euphoria, after which the guests crashed unconscious to the floor. Dr. Simpson was Chair of Midwifery at the University of Edinburgh, which hosted the best medical school in the Englishspeaking world.

Marie suffered from a narrowing of her cervix, which resulted in infertility. Simpson "cured" her by surgically enlarging the cervix with an elongated switchblade. Elizabeth was skeptical. Wouldn't it be better to try dilation before surgery, stretching the cervix with a cylinder of waxed cotton? Wouldn't surgical scarring only make Marie's stricture worse?

Simpson's treatments did not help Marie. She developed inflammation, abscesses, and ovaritis. The overuse of calomel, a mercury-based drug, produced mouth sores. "The whole case from beginning to end strikes me as a horrid barbarism," Elizabeth wrote to her sister Emily. "I see every day that it is the 'heroic,' self-reliant \& actively imposing practitioner that excites a sensation and reputation; the rational and conscientious physician is not the famous one."

"I am convinced that a new and nobler era is dawning for medicine," 
Elizabeth wrote, "when the low system of coarse \& violent drugging shall give place to a more spiritual practice, better adapted to our delicate \& wonderful living organism.” The entry of women into the medical profession would help bring about this revolution.

Armed with medical degrees, the Blackwell sisters opened the New York Infirmary for Indigent Women and Children, the first hospital staffed entirely by women, which treated more than a million patients in its first hundred years. Elizabeth stacked the Board of Trustees of the Infirmary with prominent men, including Tribune editors Horace Greely and Charles Dana, New York Times founder Henry Raymond, and jurist Theodore Sedgwick. The New York Times ran an enthusiastic article about the Infirmary, titled "What the Lady Doctors are Doing." The "homelike" establishment was "as fresh and clean as if just swept by the proverbial new broom," and the nursing care was exemplary. The Blackwell's Infirmary contrasted sharply with the unheated and overcrowded wards of city hospitals, where doctors rotated through surgeries, childbirths, and morgues without washing their hands.

The suffragettes saw in Elizabeth a natural ally, but she repeatedly rebuffed their overtures to join the movement. The organizers of the suffragette convention in Syracuse were probably relieved that Elizabeth didn't attend their meeting when they read her response to their invitation to speak. Elizabeth wrote that women's suffrage was woefully premature because women are so often "frivolous human beings.” In Elizabeth's view, women's education and professional achievement needed to precede women's voting rights.

In 1868, the Blackwell sisters opened a school of medicine for women that offered a medical education superior to that available from any existing medical school. Their school required an unprecedented three years of study. Courses of lectures built progressively from year to year, rather than simply repeating the same material. Elizabeth served as Professor of Hygiene. Emily assumed the Chair of Obstetrics. Students were tested yearly by an outside board of examiners. The College, Nimura writes, was "the embodiment of its founders: admirable, impressive, and somewhat forbidding."

Emily stayed in New York to lead the College; Elizabeth returned to England to devote her life to writing and public speaking. Elizabeth had contracted gonorrheal conjunctivitis while treating a patient. This required the surgical extraction of her left eye, 
thereby ending her surgical career and limiting her ability to practice medicine.

In 1898, Cornell Medical School began admitting female students and invited women to teach and serve as trustees. "This is very encouraging, for Coeducation means that both sexes are represented both above and below," Emily wrote. Emily was seventy-three years old when she decided that Women's Medical College had served its purpose and shut its doors. Elizabeth and Emily died just a few months apart, in 1910. The New York Infirmary for Women and Children continued to serve patients until 1981, when it merged with New YorkPresbyterian Hospital.

Nimura sets the story of the doggedly persistent Blackwell sisters in a context that is eerily contemporary. America is still a land of both infinite possibility and casual cruelty. America is still rife with conflict between men and women, Northern states and Southern states, blacks and whites. Nimura could not have anticipated that her book would appear in the midst of a pandemic that has subverted our scientific and public health dogmas and inaugurated a new era of "heroic" medicine.

Nimura packs her history into 268 pages, but one wishes her book had been longer. In footnotes and in passing paragraphs, female doctors make their appearance but Nimura leave us itching for more information about them. Rebecca Cole, for example, was the first black graduate of the Female College of Philadelphia. After finishing her thesis on "The Eye and its Appendages" in 1867, Cole joined the Blackwell's Infirmary, where, Elizabeth wrote, she "carried on this work with tact and care." Equally intriguing is James Miranda Barry, who obtained a medical degree in 1812 and rose to the rank of inspector general as a surgeon in the British army. Not until the death of this "slim, smooth cheeked man" in 1865 did the public learn that Barry was a female. Perhaps Nimura will grace us with a sequel to The Doctors Blackwell that will feature the lives of these extraordinary pioneers. 